Volume: 11 Issue: 1 Year: 2014

\title{
An example of polygenetic geomorphologic development (Karst-Glacial-Tectonics) on Munzur Mountains: Kepir Cave-Elbaba spring karstic system
}

\author{
Zeynel Çılğın ${ }^{1}$ \\ Cihan Bayrakdar ${ }^{2}$ \\ Joseph Scott Oliphant ${ }^{3}$
}

\begin{abstract}
The study area is located at the intersection of a karstic plateau basin in the Munzur Mountain range and a low-lying karstic discharge area in the Ovac1k Plain. The mountain range extends east to west and the glacial plain runs parallel in similar direction. The research area is an excellent microcosm of a polygenic morphological karst system. The mountain terrain visible today is dramatic barren landscape and the by-product of multiple, interrelated processes, such as glaciations, karstification and tectonics. The insurgence waters cut into the sediment, gain velocity, and then disappear into a seven meter high by seven meter wide swallow hole cave entrance at $2600 \mathrm{~m}$. In the past, pre-Pleistocene dolines had helped transform this area into an icefield landscape. When glaciation period ended, karstic process revived again during Holocene and Kepir Cave has operated as a swallow hole again. The main factors of change can be attributed to glaciations in Pleistocene and intensified karstification during the Holocene. The thick stacking limestone or massif provides the geologic structure for underground drainage and the formation of what may be a significant and deep cave system. The cave system appears to be developing vertically along a prominent fault that is visible just inside the swallow hole entrance. The resurgence, Elbaba, must be related to the Ovacik Fault extending at the northern edge of Ovacik Plain. This karstic system continues to develop as an active system fed by significant snow and rain waters.
\end{abstract}

Keywords: Munzur Mountains, karstic spring, polygenic morphology, swallow hole cave.

\footnotetext{
${ }^{1} \mathrm{PhD}$, Istanbul University, Institute of Social Sciences, Division of Geography (graduated), zeynelcilgin@gmail.com

${ }^{2} \mathrm{PhD}$, Istanbul University, Faculty of Letters, Department of Geography, cihanbyr@istanbul.edu.tr

${ }_{3}^{3}$ Master, Alpine Karst Foundation, qigong2007@hotmail.com
} 
Çılğın, Z., Bayrakdar, C. \& Oliphant, J. S. (2014). An example of polygenetic geomorphologic development (KarstGlacial-Tectonics) on Munzur Mountains: Kepir Cave-Elbaba spring karstic system. International Journal of Human Sciences, 11(1), 89-104. doi: 10.14687/ijhs.v11i1.2724

\section{Introduction}

The study area comprising Kepir Cave, as a swallow hole and the Elbaba Spring is located in the middle of the southern slope of the Munzur Mountains in Tunceli province, Eastern Anatolia, Turkey (Photo 1). The Elbaba Spring is the source of the Havuzlu Stream which is between the villages of Gözeler and Havuzlu villages and located at the northeast edge of Ovacık Plain. Before merging with the Munzur River the Havuzlu stream changes name to Değirmendere near the village of Güneykonak (Figure 1).

The southern slope of the Munzur Mountains is bordered by the Ovac1k fault and numerous springs demarcate this fault zone. The source of these springs or the insurgence area is the glaciokarstic basin located at an elevation of $2500-2700 \mathrm{~m}$. The underground system is fed by vertically developed swallow holes, dolines, sinkholes and caves. The karst-fed waters permeate through the massif and resurge at $1300 \mathrm{~m}$ near the Ovac1k Fault (Figure 1).

In this study, we will attempt to explain the geomorphologic evolution of the karstic spring, Elbaba. We theorize this resurgence is the result of polygenetic geomorphology whose processes include glaciations, karstification, and fluvial tectonics. In this regard, the explanation of the geomorphologic evolution of Elbaba Spring is regionally important for it could give valuable insight about the evolution of similar resurgent springs in different areas the Munzur Mountains.

The data sources of this study are comprised of 1:25000 scaled topo-maps; 1:100000 and 1:500000 scaled geological maps; DEM, created with counter lines $10 \mathrm{~m}$ resolution; GPS measurements, Satellite images (2002 Geo Eye satellite images) and maps produced following field studies carried out in the summers of different years $(2011,2012,2013)$. Enhanced by means of high-resolution satellite images, 3D and spatial analyses have been applied to create a sophisticated database using Geographic Information Systems (GIS) software (ArcMap 10).

\section{Geology}

The Munzur Mountain Range is located on the northeastern edge of the Taurus Orogenic Belt, which is cut by the North Anatolian Fault. These mountains exhibit characteristics consistent with this significant geologic feature. Some rock formations which tectonically converge on the western and middle part of this geologic belt also cover wide areas of the Munzur Mountain range (Figure 2). Munzur limestone, which is mostly formed by shelf-type carbonates, represents a large part of the Mesozoic period (upper Trias-upper Cretaceous). This thick carbonate stack, being tectonically in contact with other units of the region has peculiar rocks and stratigraphic properties that separate it from other units. Significance in terms of karst development is that it constitutes a single 
Çı̆ğın, Z., Bayrakdar, C. \& Oliphant, J. S. (2014). An example of polygenetic geomorphologic development (KarstGlacial-Tectonics) on Munzur Mountains: Kepir Cave-Elbaba spring karstic system. International Journal of Human Sciences, 11(1), 89-104. doi: 10.14687/ijhs.v11i1.2724

tectonic-stratigraphic unit. Most of the formation is composed of shelf-type neritic limestone. The dominant rocks are algea and reef-type limestone. Oolitic and pelagic limestones are found in the middle and upper parts of the mountain, respectively (Özgül 1981).

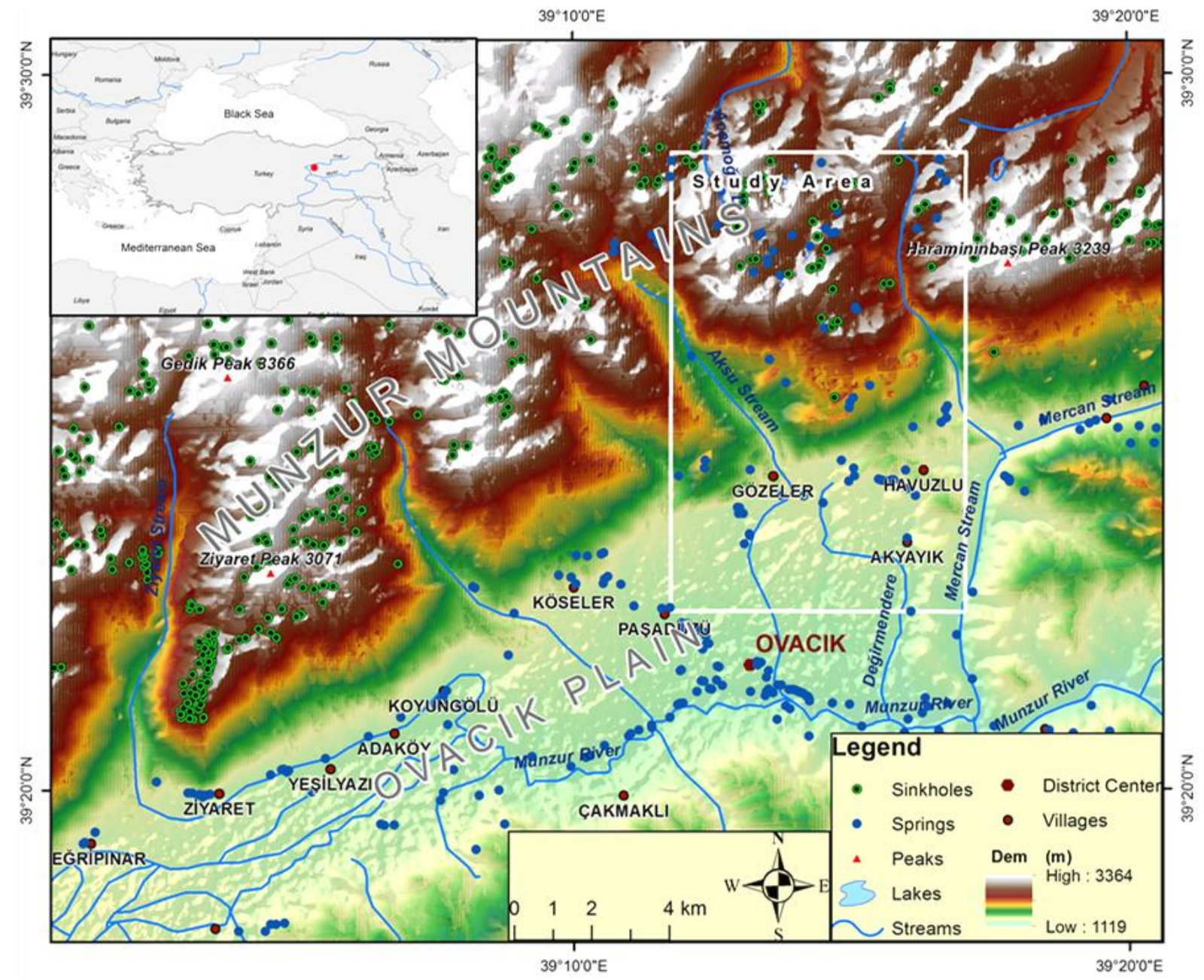

Figure 1: The location of the study area.

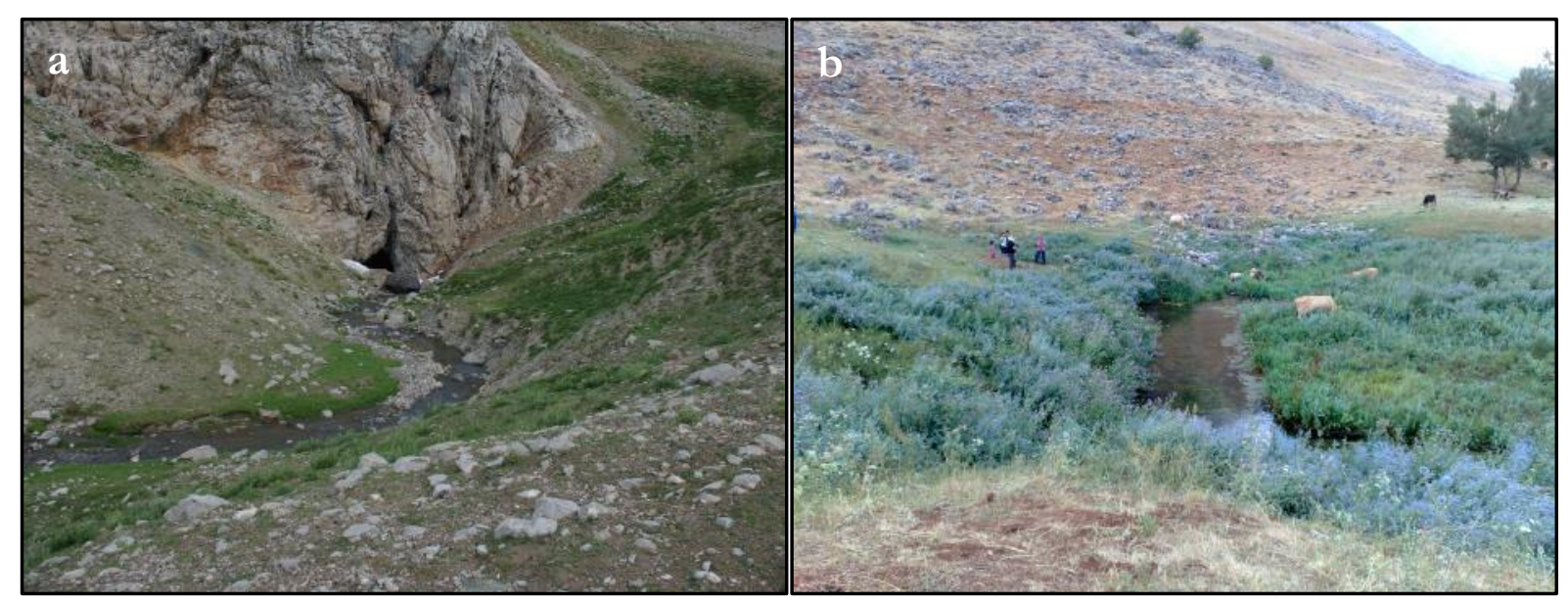

Photo 1: The Kepir Sinkhole at the elevation of $2600 \mathrm{~m}$ on the Munzur Mountain (a) and The Elbaba Spring at the elevation of $1380 \mathrm{~m}$. 
Çılğın, Z., Bayrakdar, C. \& Oliphant, J. S. (2014). An example of polygenetic geomorphologic development (KarstGlacial-Tectonics) on Munzur Mountains: Kepir Cave-Elbaba spring karstic system. International Journal of Human Sciences, 11(1), 89-104. doi: 10.14687/ijhs.v11i1.2724

The study area, which covers just a fraction of the Munzur Mountain range, is mostly composed of Munzur Limestone units. Some moraines have persevered and remain visible on the upper flat areas and glacial troughs, especially on the trough endings. In addition, the outwash plain was formed by pro-glacier streams, which transported and deposited these moraines as well as the Quaternary-age alluvial deposits formed by fluvial processes. These all make up a large part of Ovacik Plain (Figure 2).

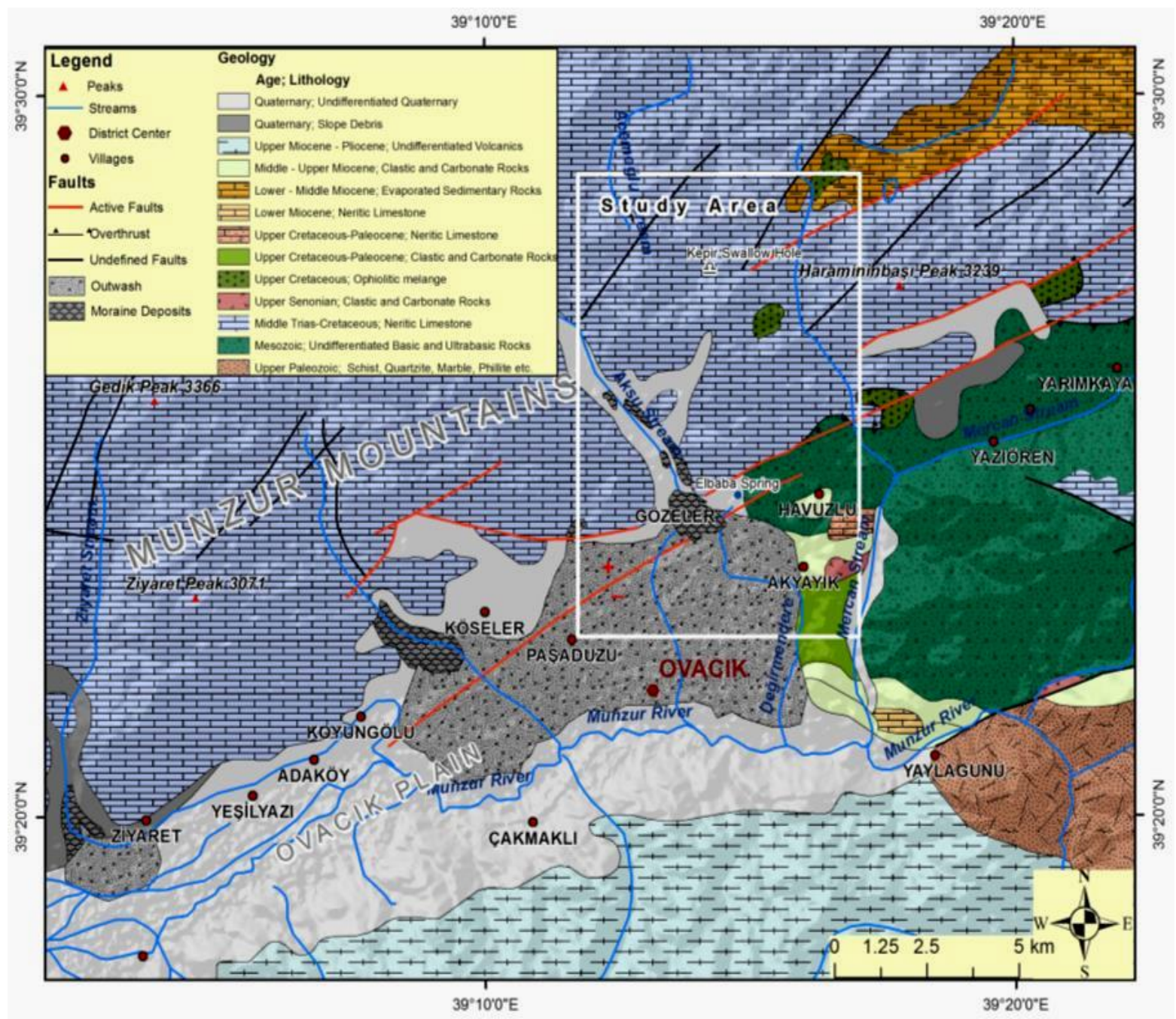

Figure 2: The geologic features of the study area and its surroundings (modified from Özgül 1981)

\section{Tectonics}

The existence of an active fault extending WSW to ENE and intersecting with the southern slopes of the Munzur Mountain Range and Ovacik Plain has been confirmed by researchers (Figure 2). However, there are different opinions as to how this fault is defined. Özgül (1981), Arpat and Şaroğlu (1975) believe it is a normal fault. On the other hand, Westaway and Arger (2001) claim that the fault is strike-slip fault system and a segment of the Malatya-Ovac1k Fault. According to 
Çılğın, Z., Bayrakdar, C. \& Oliphant, J. S. (2014). An example of polygenetic geomorphologic development (KarstGlacial-Tectonics) on Munzur Mountains: Kepir Cave-Elbaba spring karstic system. International Journal of Human Sciences, 11(1), 89-104. doi: 10.14687/ijhs.v11i1.2724

Arpat and Şaroğlu (1975), the traces of a recent and active fault can be seen in new deposits visible on the southern slope of the Munzur Mountains and in the north of Ovac1k Plain. This fault cuts the outwash plain produced by pro-glacier streams on the Munzur Mountain Range during the Pleistocene period. The fault plain is almost flat. However, a slight inclination towards the south can be seen in the bed of a stream located between Yilanlı and Karataş villages. This particular feature of the fault is significant as this segment diverges from the main branch and extends towards the southwest in a concave manner and illustrating the southeast bloc of the fault is lower. The traces of the fault between Paşadüzü and Koyungölü appear as closed pits. The fault steepness in the immediate southwest of Karataş village faces towards the north (Arpat \& Şaroğlu, 1975), (Figure 3).

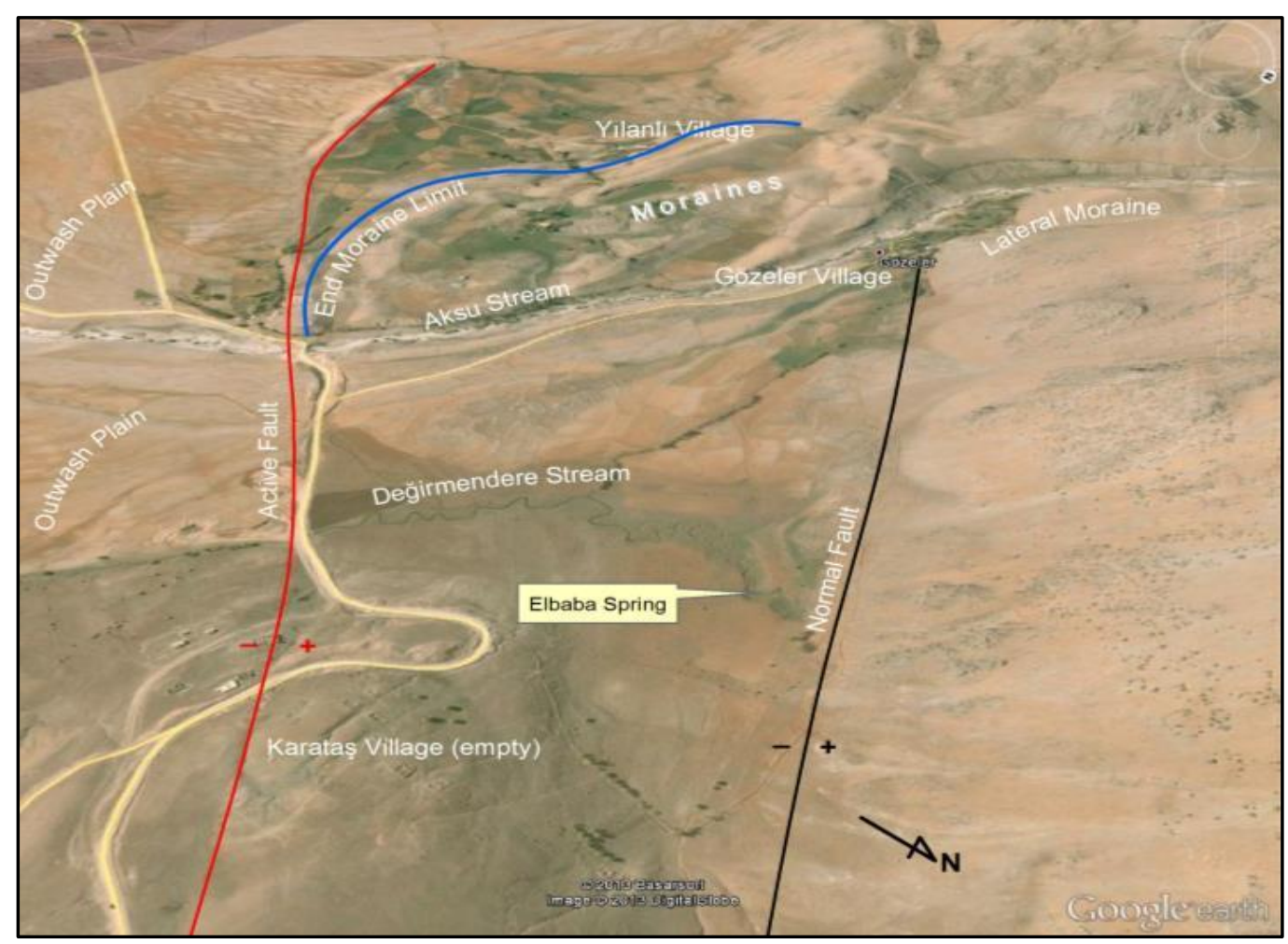

Figure 3: The faults around the Elbaba Spring (modified from Özgül 1981, Arpat \& Şaroğlu, 1975)

On the other hand, Westaway et al (2007) put forward the idea that the strike-slip fault is attributed to location and timing. The area is strategically situated between the Anatolian, African and Arabian plates and probably occurred during upper Miocene-middle Pliocene (between 7-6 My and 3.5 My). During that time, the Malatya-Ovac1k Fault Zone (MOFZ) formed the border of the Anatolian and Arabian plate instead of the East Anatolian Fault Zone (EAFZ), like today. There are significant differences between Pliocene fault geometry and modern fault geometry. The first is the trans-tensional geometry of the MOFZ, the modern EAFZ being typically a left-lateral 
Çılğın, Z., Bayrakdar, C. \& Oliphant, J. S. (2014). An example of polygenetic geomorphologic development (KarstGlacial-Tectonics) on Munzur Mountains: Kepir Cave-Elbaba spring karstic system. International Journal of Human Sciences, 11(1), 89-104. doi: 10.14687/ijhs.v11i1.2724

transform fault zone with localized transtensions. The second difference is that the MOFZ slip rate was much less than the 9-10mma-1 EAFZ slip rate; the rate is estimated as $\sim 2-3 \mathrm{mma}-1$, having produced no more than $\sim 8 \mathrm{~km}$ of slip during its approximately three million year-long activity. The Malatya and Ovacik faults were both transtensional, but with left-lateral slip becoming gradually predominant (Westaway, Demir, \& Seyrek, 2007).

\section{Karst Geomorphology}

The Eastern Anatolian karst region's Permian, Jura and Cretaceous carbonate rocks in the Taurid tectonic belt, including the Munzur Mountains, have been compressed and uplifted since the middle of the Miocene. The region's karstic base level, which was determined by Ophiolite mélange, climate and tectonics, could not distinctly form solely due to the stratigraphic position of soluble rocks. Because of this situation, it appears that the karstification may have no horizontal and vertical continuity. Tectonically controlled fluvio-karstic basins and poljes that evolved during the paleo-karstic period in the region dissected deeply by the Euphrates and Aras rivers, developed horizontally rather than vertically. The basins which were captured and whose insides were swept by younger streams have characteristic forms of epikarst. In contrast, the Munzur Mountains are composed of Jurassic and Cretaceous-aged rocks and has karstic landforms exhibiting polycyclic characteristics. Further, karstification has developed vertically and perhaps quite deep in some parts of the mountains where a cold climate and a period of glaciations prevailed (especially during Würm glaciation) (Nazik \& Tuncer, 2010).

The Munzur Mountains are mostly composed of upper Triassic-upper Cretaceous neritic limestones with a thickness that surpasses $1000 \mathrm{~m}$ from place to place (Özgül, 1981). Intensive karstification unique to the Taurus developed in thick massive limestones, and shows significant continuity in both vertical and horizontal directions (Atalay, 2003; Atalay, Karadoğan, \& Yildırım, 2012). As a result, karstification on the Munzur Mountain Range above 2500m has occurred; including large number of dolines, uvalas and fluvio-karstic depressions. These karstic features, also known as insurgence areas, facilitate drainage of surface water into underground drainage systems via sinkholes and swallow holes, some of which form the upper part or openings of caves. These karstic systems resurge as voluminous karstic springs now and then, wherever impermeable ophiolites create a karstic base level and/or this thick limestone stack is cut by faults. Kepir Basin, which is a section of the study area, is on the southern part of The Munzur Mountain Range. Kepir Basin, is situated at an altitude zone between $2600-2700 \mathrm{~m}$ and covers a large area $\left(1,52 \mathrm{~km}^{2}\right)$. It is enclosed basin and this further supports and promotes the formation of depression, sinkholes and swallow holes. These sinkholes and swallow holes constitute the starting points of vertical karst due 
Çılğın, Z., Bayrakdar, C. \& Oliphant, J. S. (2014). An example of polygenetic geomorphologic development (KarstGlacial-Tectonics) on Munzur Mountains: Kepir Cave-Elbaba spring karstic system. International Journal of Human Sciences, 11(1), 89-104. doi: 10.14687/ijhs.v11i1.2724

to the existence of thick limestone. The karstification on the former plateau is presently in $200 \mathrm{~m}$ zone and begins around $2500 \mathrm{~m}$. It is speculated that it may have developed horizontal karst in ancient times when the Munzur Mountain Range was at a much lower elevation than today. Due to the tectonic uplift that has occurred during the neotectonic period, the process of karstification shifted vertically and this was instrumental in helping sinkholes and swallow holes develop (Photo 2). Kepir Basin is an uvala that has formed through the merging of many dolines. Surface drainage of this uvala becomes an underground drainage after the waters enter the swallow hole named Kepir Düden. This is the starting point of Kepir Cave, located in the east of the uvala. Kepir Stream, which is fed by year around sources that becomes more active during the snow melt in spring and summer from the cirque lakes (tarns) around the uvala. These waters flow an estimated $2.2 \mathrm{~km}$ on the uvala surface toward the east before steeply downcutting and plunging into Kepir Düdeni to become part of underground drainage system (Photo 2). This superficial fluvial system and associated underground development appears uniquely enhanced by a mixed denudation system (Ford \& Williams, 2007) consisting of an autogenic stream that is fed by allogenic waters.

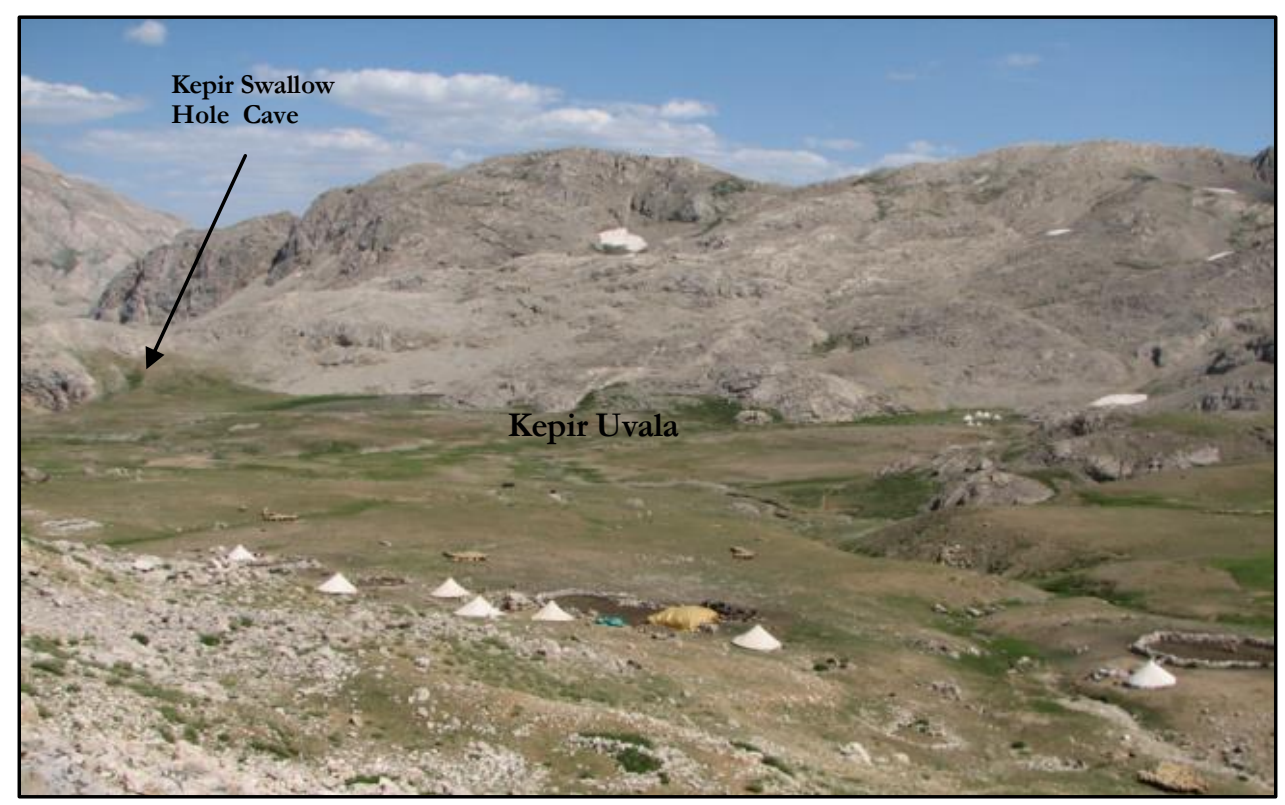

Photo 2: The Kepir Karstic Depression and the swallow hole cave, view from NW.

\section{Glacial Geomorphology}

The Munzur Mountain Range has exhibits erosional and depositional glacial landforms due to glaciations during the cold periods of the Pleistocene (Atalay, 1983; Atalay, 1987). In those periods, temperatures and the equilibrium line altitude (ELA) dropped due to changes in climate. While the ELA is currently estimated at the altitude of $3600-3700 \mathrm{~m}$, it has actually descended to around 2750 $\mathrm{m}$ during the cold periods of the Pleistocene (Bilgin,1972). 
Çılğın, Z., Bayrakdar, C. \& Oliphant, J. S. (2014). An example of polygenetic geomorphologic development (KarstGlacial-Tectonics) on Munzur Mountains: Kepir Cave-Elbaba spring karstic system. International Journal of Human Sciences, 11(1), 89-104. doi: 10.14687/ijhs.v11i1.2724
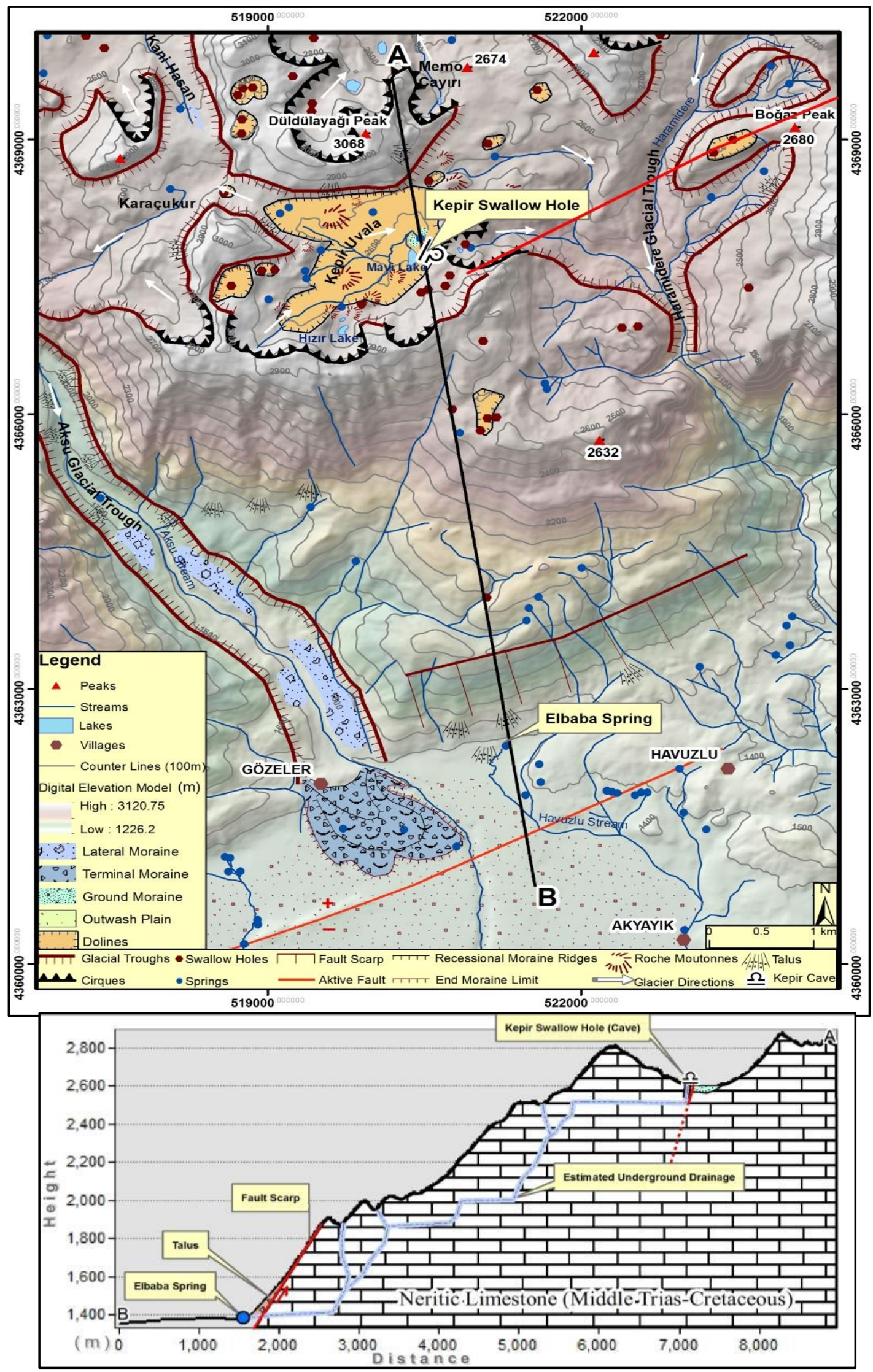

Figure 4: The geomorphological map of the study area and the cross-section of the Kepir Sinkhole and The Elbaba Spring. 
Çılğın, Z., Bayrakdar, C. \& Oliphant, J. S. (2014). An example of polygenetic geomorphologic development (KarstGlacial-Tectonics) on Munzur Mountains: Kepir Cave-Elbaba spring karstic system. International Journal of Human Sciences, 11(1), 89-104. doi: 10.14687/ijhs.v11i1.2724

Glaciations on Munzur Mountain during Pleistocene were mostly alpine-type glaciation; however, in addition to this, some plateau type glaciations occurred on gently sloping areas or old karstic basins surrounded by cirques behind the upper end of the valleys. Cirques, valley and plateau glaciers combined or erased by each other.

The plateau glaciers were fed by cirques and valley glaciers were fed by the plateau glaciers that were behind them. It is obvious from the glacier troughs, glacier tongue depressions, and moraines that the lobes of the valley glaciers descended to $1600 \mathrm{~m}$ generally and even lower to $1400 \mathrm{~m}$ where the glacier trough ended in the Ovack Plain (Bilgin, 1972). Some parts of the study area are of great significance with regard to having undergone plateau-type glaciation. The former glaciers in this area were fed by cirques, especially those facing north, and they covered the entire Kepir closed basin or depression, which was characterized by plateau ice at that time. The traces of the trim line of the glaciers in this area can be seen at an elevation of about $2800 \mathrm{~m}$. It is also evident that the plateau ice reached $200 \mathrm{~m}$ thickness, and, based on morphologic evidence such as combining trim lines and glacially eroded mountain passes, the ice of Kepir Plateau merged with the ice of neighboring plateau e.g. Karaçukur and Ganihesen in the West and Memo Çayırı in the northeast. The main drain flow direction of Kepir Plateau glacier was initially towards the East, and then the ice turned Southern part due to topographic conditions, afterwards continuing as the Haramidere Glacier. A result of glaciations, cirques, roche moutonnees, glacier troughs, pulverized surfaces and moraines constitute the traces of glacial morphology that we can see today (Photo 3).

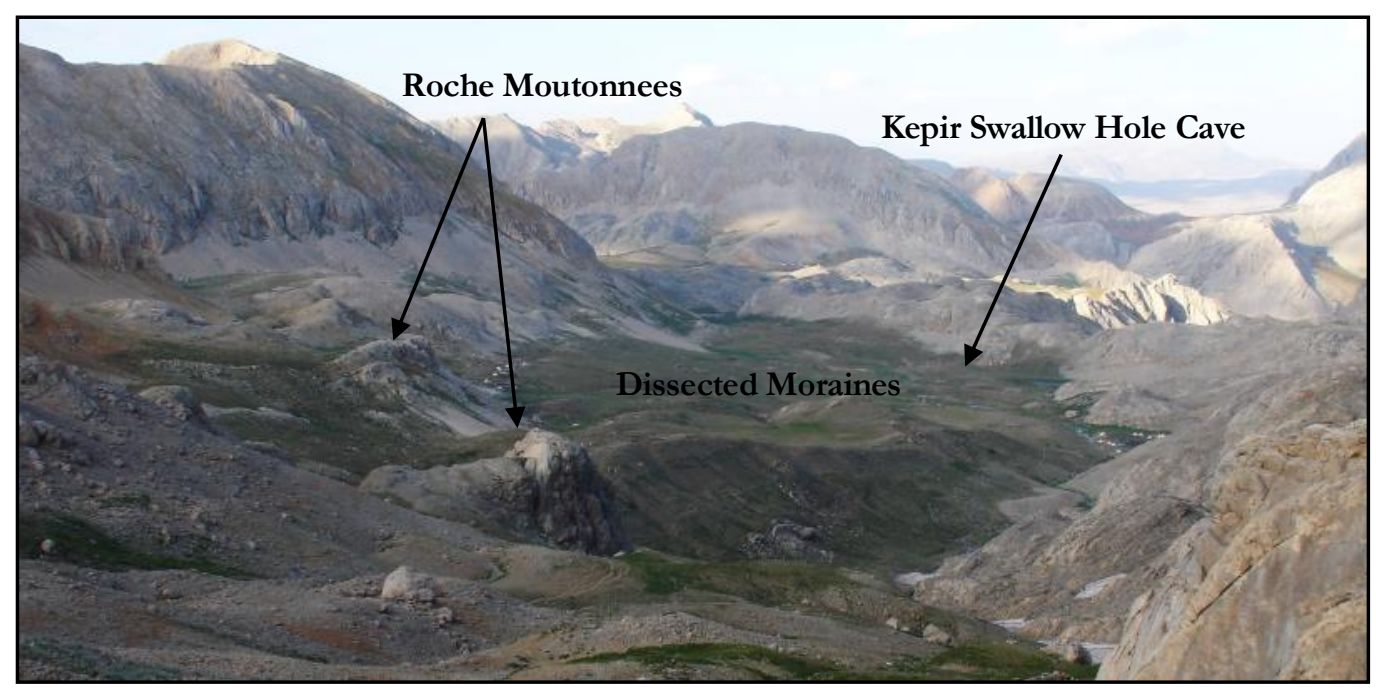

Photo 3: Kepir glacio-karstic basin, view from SW.

\section{Karst, Glaciers and Tectonic relationship.}

Several processes have played roles in the geomorphologic evolution of the Munzur Mountain Range. The foremost of these processes are karstification, glaciation, tectonics, and fluvial 
Çılğın, Z., Bayrakdar, C. \& Oliphant, J. S. (2014). An example of polygenetic geomorphologic development (KarstGlacial-Tectonics) on Munzur Mountains: Kepir Cave-Elbaba spring karstic system. International Journal of Human Sciences, 11(1), 89-104. doi: 10.14687/ijhs.v11i1.2724

processes. While tectonic activity is significant for the whole of the Munzur Mountain Range, karst, glaciation and their associate landforms are mostly confined to an area above $2500 \mathrm{~m}$. These landforms are complex and frequently intertwined with each other. Neotectonics and climate changes in the Quaternary period have had a great impact and influence in the formation of this polygenetic scenery.

Karstification on the Munzur Mountain Range started in the Oligocene period and developed in a mostly vertical manner during the warmer and more humid climate times during the Miocene. It was then that the karstic processes began to form its first karstic depressions above the $2500 \mathrm{~m}$ on Munzur. Moreover, intensification of tectonic activity resulted in uplift in the Pliocene and this caused the karstic base level to deepen and karstification to shift more vertical (Erinç, 1970; Ardos, 1979; Erol, 1979; Nazik \& Tuncer, 2010).

With the climate changes in the Pleistocene, cold and warm periods had a more distinct weather pattern than before. In particular, paleo-karstic depressions on the higher part of the Munzur Mountain Range were occupied and extensively deformed by glaciers. In the warmer periods, karstification revived. These cycles continued until the beginning of the Holocene. Due to these cycles in the Pleistocene, some part of the former uvala basin (now $2700 \mathrm{~m}$ high) must have developed before glaciations can be seen in the northern, western, and southern directions of the sides of the present uvala basin (now at approximately $2600 \mathrm{~m}$ ). Even though these polycyclic uvala basins have been cut by streams from place to place, they generally appear flat or with gently sloping surfaces (Photo 4).

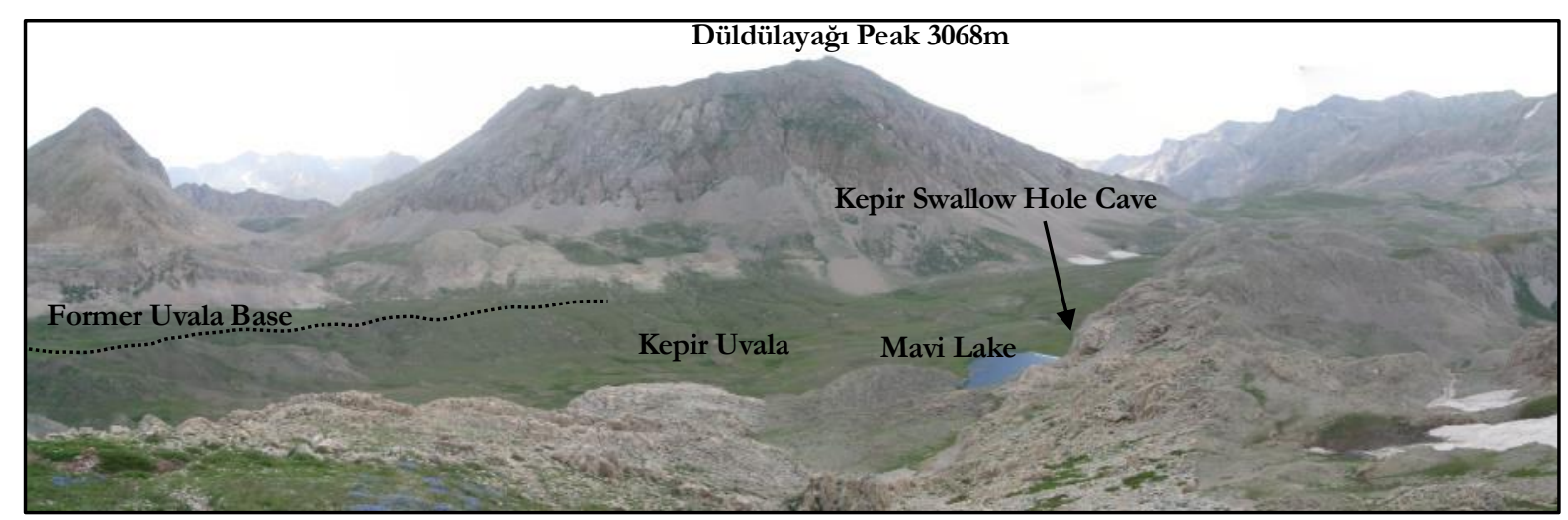

Photo 4: The polycyclic levels in the Kepir Karstic Depression.

These cycles also profoundly affected the development of the Kepir swallow cave and Elbaba spring. The position of Kepir swallow hole and its morphological properties indicate that the cave existed before the glacial periods. While Kepir swallow hole was an active cave and part of the underground drainage system that drained the waters of the Kepir Uvala before the last glacier period, its development was substantially interrupted due to glaciers covering the Kepir Uvala. 
Çılğın, Z., Bayrakdar, C. \& Oliphant, J. S. (2014). An example of polygenetic geomorphologic development (KarstGlacial-Tectonics) on Munzur Mountains: Kepir Cave-Elbaba spring karstic system. International Journal of Human Sciences, 11(1), 89-104. doi: 10.14687/ijhs.v11i1.2724

Even though karstification was extensively hindered by glaciers above ELA during glacier periods, it cannot be said for certain that there was no karstification. In glaciated areas with warm ice, like the study area, water was present as a thin film layer in cavities in the glacier bed. Thin films of water sometimes less than $1 \mathrm{~mm}$ in thickness covered the entire glacier bed. This thin film of water continuous freeze and thaw conditions exist (Smart, 2004). Due to this cyclical process, melting and seeping waters might have partially kept open semi-active paleo-swallow hole like Kepir cave or other glaciated areas on the Munzur Mountain range.

While glaciers retreated towards cirques around the Kepir Uvala, they covered Kepir Cave's mouth with moraines up to $40 \mathrm{~m}$ thick (Photo 4). With the end of glaciations nearing, the moraines covering the cave mouth collapsed and were swept inside the cave via the superficial waters' orientation towards the cave further enhancing underground drainage again. Owing to the acceleration of fluvial activity, the moraines covering the uvala basin were largely dissected and transported by the Kepir stream. Although the moraines were dissected and transported by the stream, some remnant of them can be seen around the cave opening as being patched on the slopes (Photo 5).

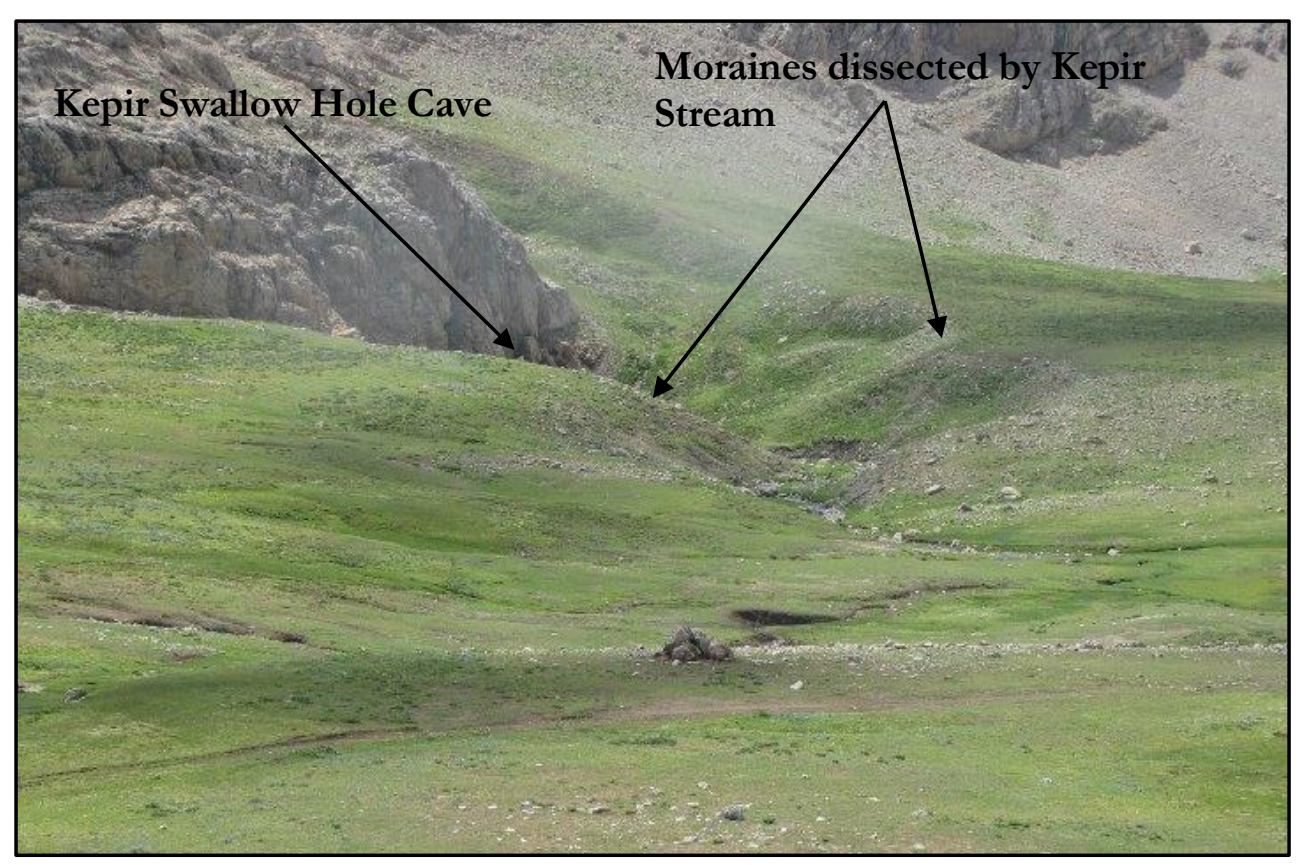

Photo 5: The Kepir Swallow Hole Cave and incised moraines around it.

Kepir swallow hole which developed vertically on a fault oriented ENE-WSW on the Kepir Basin is a deep hole-shaped cave comprised of Triasic-upper Cretaceous neritic limestone (Photo 6). The cave's mouth has $7 \mathrm{~m}$ width by $7 \mathrm{~m}$ height and just $15 \mathrm{~m}$ inside of the cave hollow become larger having up to $43 \mathrm{~m}$ height of clearance. The cave extends approximately $25 \mathrm{~m}$ towards the East in a 
Çılğın, Z., Bayrakdar, C. \& Oliphant, J. S. (2014). An example of polygenetic geomorphologic development (KarstGlacial-Tectonics) on Munzur Mountains: Kepir Cave-Elbaba spring karstic system. International Journal of Human Sciences, 11(1), 89-104. doi: 10.14687/ijhs.v11i1.2724

cascading manner; after that, it turns Southeast, then South with a waterfall being the furthest point of exploration. Exploration beyond this point requires advance single rope techniques due to strong stream-current and waterfall (Photo 6, Figure 5). The existence of a fault oriented ENEWSW both on the Kepir swallow hole and on the Elbaba discharge indicates that the formation of the Kepir swallow hole and Elbaba discharge has been controlled by these faults. Furthermore, the levels formed by different periods of uplift attributed to tectonic activity can be seen on the southsloping profile of the Munzur Mountains between Kepir swallow hole (2600 m) and Elbaba spring $(1380 \mathrm{~m})$ (Figure 4). We conclude that even though the cave could partly form nearly horizontally at $2000 \mathrm{~m}$ and $2500 \mathrm{~m}$, it most likely continues vertically to a great extent because of the existence of the fault mentioned earlier (Figure 4).
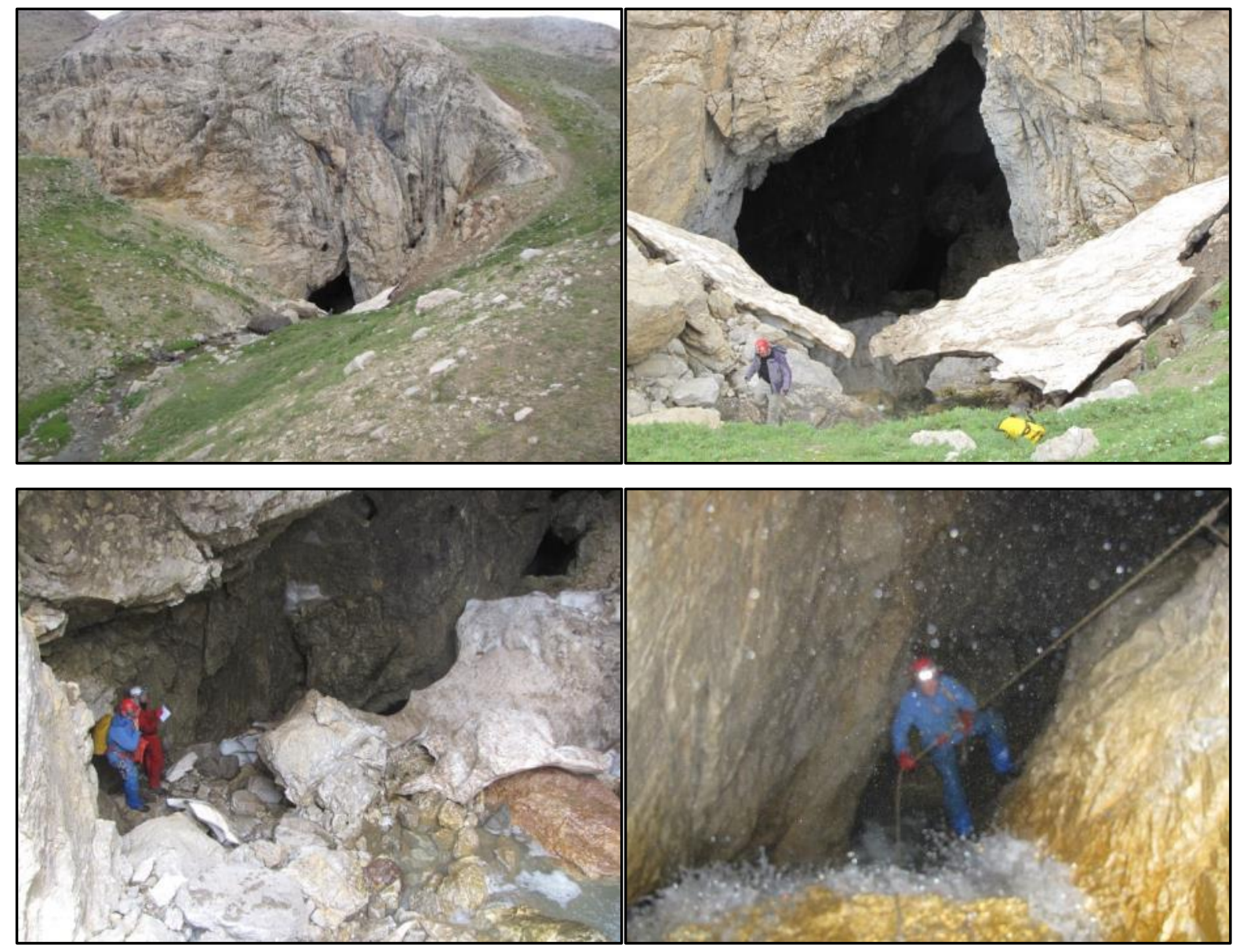

Photo 6: View of Kepir Swallow Hole Cave from different aspects

Uplift process has taken place on the Munzur Mountains due to tectonic activity, and subsequently the karst base level lowered. The Kepir swallow hole feeds an underground drainage system that has been cut by an active fault crossing Ovacik Plain. This aquifer resurges as Elbaba Spring (Photo 7). While canyons such as Haramidere in the east and Aksudere to the west of Elbaba 
Çılğın, Z., Bayrakdar, C. \& Oliphant, J. S. (2014). An example of polygenetic geomorphologic development (KarstGlacial-Tectonics) on Munzur Mountains: Kepir Cave-Elbaba spring karstic system. International Journal of Human Sciences, 11(1), 89-104. doi: 10.14687/ijhs.v11i1.2724

Spring incise the Munzur Mountain range. In this area, there are no voluminous springs, only sparse seep of water in the prominent canyons. The insurgent water that enters into the Kepir swallow hole would be expected to resurge in Haramidere Canyon, located east of Kepir Cave, due to the orientation of the cave and due to its proximity with ophiolite rocks operating as an impermeable layer and directing underground drainage towards the south (Figure 2, 5).

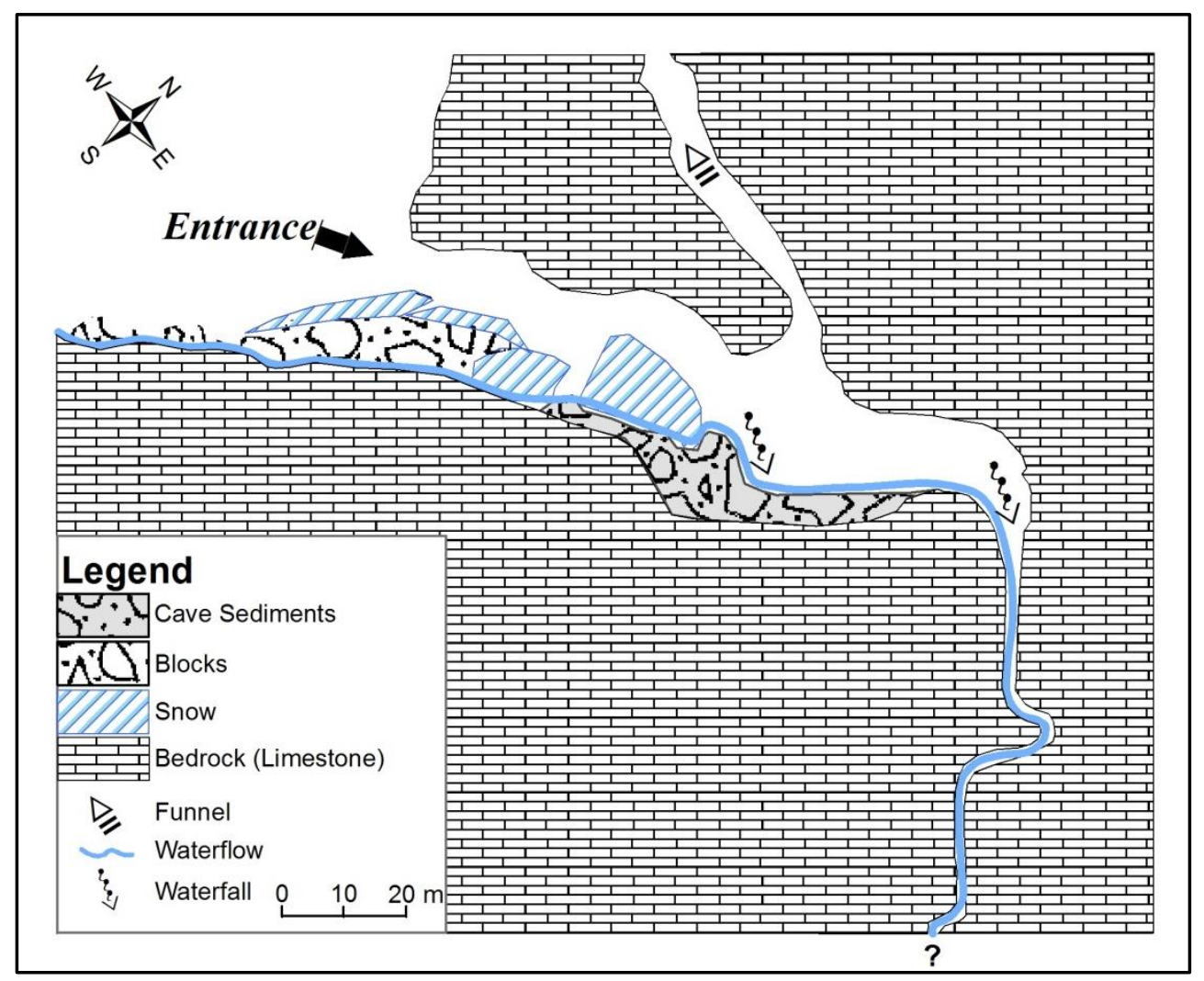

Figure 5: The plan of Kepir Swallow Hole Cave

The flow rates of the Kepir Stream and Elbaba Spring have been measured with the float (crosssectional) method (Harrelson et al., 1994). The results gathered calculated flow rates of 0,077 $\mathrm{m}^{3} / \mathrm{sec}$ (77 liters/sec) for the Kepir Stream (measurement section was $30 \mathrm{~m}$ behind the Kepir Swallow Hole) and $0,359 \mathrm{~m}^{3} / \mathrm{sec}$ (359 liters/sec) for the Elbaba Spring (measurement was $50 \mathrm{~m}$ ahead of Elbaba Spring). The flow rate of Elbaba Spring is five times as voluminous as Kepir Stream and given the basin size of the insurgence area this is not unexpected. These results suggest that Elbaba Spring is not only fed by Kepir Stream, it also implies that the area located between Kepir Uvala and Elbaba Spring must send its superficial waters into an underground system, as indicated by the suitable properties of karstic rocks, and be fed by underground waters, too. As mentioned above, Kepir Cave and Elbaba Spring constitute components of a more extensive karstic underground drainage system. 
Çı̆ğın, Z., Bayrakdar, C. \& Oliphant, J. S. (2014). An example of polygenetic geomorphologic development (KarstGlacial-Tectonics) on Munzur Mountains: Kepir Cave-Elbaba spring karstic system. International Journal of Human Sciences, 11(1), 89-104. doi: 10.14687/ijhs.v11i1.2724
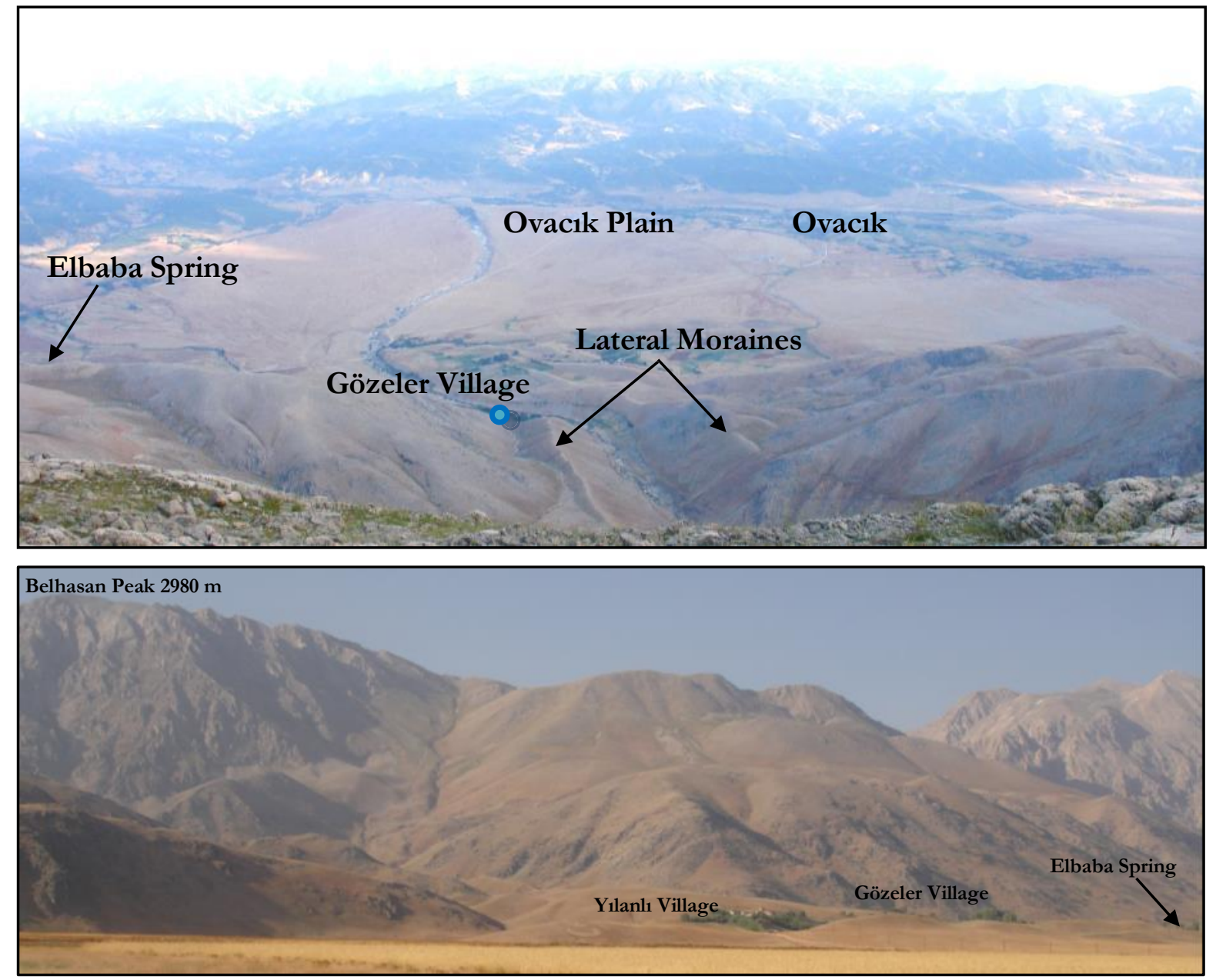

Photo 7: View of the Elbaba Spring from Belhasan Peak and Ovacik Plain.

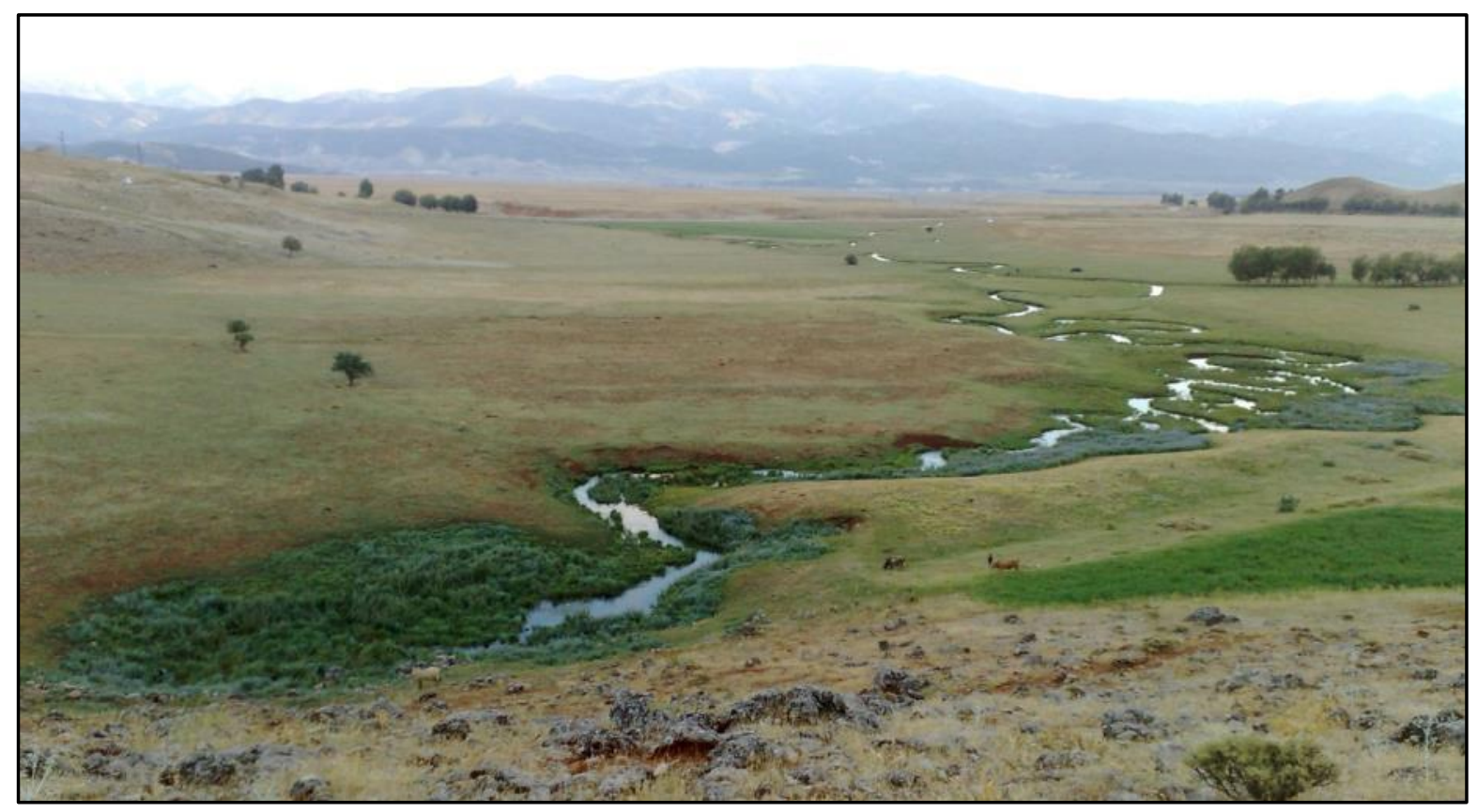

Photo 8: The Elbaba Spring originating Havuzlu Stream. 
Çılğın, Z., Bayrakdar, C. \& Oliphant, J. S. (2014). An example of polygenetic geomorphologic development (KarstGlacial-Tectonics) on Munzur Mountains: Kepir Cave-Elbaba spring karstic system. International Journal of Human Sciences, 11(1), 89-104. doi: 10.14687/ijhs.v11i1.2724

\section{Conclusion}

The Kepir Cave-Elbaba Spring karstic system started to develop with the uplift of Munzur Mountain and thrived during the pre-glacial periods. Even though the system was substantially interrupted by glacial periods, it revitalized and continued its intensification development during the interglacial periods and the Holocene. Apart from karstification and glaciation, tectonics (especially normal faults) has had a significant role in the speleogenesis of the system. The study area represents a relatively microcosm of the karstic underground system of the Munzur Mountain Range, which normally has a far more complex underground drainage than this. In this respect, the model and insight provided here of this underground drainage system has developed in accordance with karstification, glaciation, and tectonics and the analysis, evaluations, and conclusions can be applied to other areas on the Munzur Mountain range wherever some or all of the same conditions exist. This is very important with regard to the detection and sustainable usage of fresh-water sources, which have come into significant importance recently. Furthermore, this study may offer a pattern for projects that focus on protection and sustainable usage of the water catchment areas on Munzur Mountain.

Acknowledgements: We are grateful to Peter Orte, doctoral candidate at the University of Wisconsin, Madison - Department of Comparative Literature, as the copy editor of this paper and for his cartography efforts to produce an accurate map and representation of the cave.

\section{References}

Ardos, M. (1979). Türkiye Jeomorfolojisinde Neotektonik. İstanbul: İstanbul: İst. Üniv. Coğr. Enst.Yay. No:113.

Arpat, E., \& Şaroğlu, F. (1975). Türkiye'deki bazı önemli genç tektonik olaylar: Türkiye Jeol. Kur.Bült., 18,1,91-101. Türkiye Jeol. Kur.Bült (págs. 91-101). Ankara: MTA.

Atalay, İ. (1983). Mescit Dağının glasyal jeomorfolojisi. Ege Coğrafya Dergisi, 2, 31-48.

Atalay, İ. (1987). Türkiye Jeomorfolojisine Giriş (2. Baskı). İzmir: EÜ. Edebiyat Fakültesi Yay. No:9.

Atalay, İ. (2003). Effects of the tectonic movements on the karstification in Antolia. Acta Karstologia. 32 (2)., 195-203.

Atalay, İ., Karadoğan, S., \& Yıldırım, A. (2012). Karstification and ground river system in the SE Anatolia. Potentials and problems of natural environment in Turkey and Romania. Proceedings the 7th Turkey-Romanian Geographical Academic Seminar. Eds.: Atalay, Ielenicz, Balteanu and Efe (págs. 81-82). İstanbul: Inkilap .

Bilgin, T. (1972). Munzur Daglar Dogu Kısmının Glasiyal ve Periglasiyal Morfolojisi. İstanbul: İstanbul Üniversitesi Yayınlar1 No:1757, Cografya Enstitüsü Yayınlar1 No: 69. 
Çılğın, Z., Bayrakdar, C. \& Oliphant, J. S. (2014). An example of polygenetic geomorphologic development (KarstGlacial-Tectonics) on Munzur Mountains: Kepir Cave-Elbaba spring karstic system. International Journal of Human Sciences, 11(1), 89-104. doi: 10.14687/ijhs.v11i1.2724

Erinç, S. (1970). Türkiye Kuaterneri ve Jeomorfolojinin Katkısı. Jeomorfoloji Dergisi S.2, 12-35.

Erol, O. (1979). Türkiye'de Neojen ve Kuaterner Aşınım Dönemleri, Bu Dönemlerin Aşınım Yüzeyleri ile Yaşıt (Korelan) Tortullara Göre Belirlenmesi. Jeomorfoloji Dergisi S.8, 1-40.

Nazik, L., \& Tuncer, K. (2010). Türkiye Karst Morfolojisinin Bölgesel Özellikleri. Türk Speleoloji Dergisi S.1, 9-17.

Özgül, N. (1981). Mun₹̧r Dağlarmm Jeolojisi. Ankara: Basılmamış MTA Raporu.

Smart, C. (2004). Glacierized and Glaciated Karst. En J. Gunn, Encyclopedia of Cave and Karst Science (págs. 804-809). London: Taylor \& Francis Books, Inc.

Westaway, R., Demir, T., \& Seyrek, A. (2007). Geometry of the Turkey-Arabia and Africa-Arabia plate boundaries in the latest Miocene to Mid-Pliocene: the role of the Malatya-Ovacik Fault Zone in eastern Turkey. eEarth Discussions 2, 169-190. 